\title{
The Research on the Evaluation System of Sustainable Development of Chongqing Economy
}

\author{
Fei LU \\ Chongqing Academy of Social Sciences, Chongqing 400020, China
}

\begin{abstract}
The sustainable development is the standard of development which has been recognized by countries all over the world. Chongqing city is located in the western underdeveloped region, with a large population, relatively scarce resources and big gap between urban and rural areas. It is significant to implement the strategy of sustainable development, with the mutual coordination and promotion among the economic benefits, environmental benefits and social benefits. To evaluate the sustainable development in Chongqing city and its counties, we should develop the application of the related data systematically, scientifically and frequently to descript, test and evaluate the economy sustainable development of Chongqing city and its counties timely. The author intends to set up a set of appropriate regional economy sustainable development index system to measure and evaluate the development status, level and ability of the regional economy of Chongqing City and its counties.
\end{abstract}

KEYWORD: The sustainable development; The he evaluation system

\section{THE CONNOTATION OF SUSTAINABLE DEVELOPMENT OF CHONGQING ECONOMY}

The sustainable development includes the ecology sustainable development, economy sustainable development and society sustainable development which is the mutual coordination and promotion process among the economic benefits, environmental benefits and social welfare. [1] The sustainable economy development can encourage economic growth and the later is the premise to realize the former. The ultimate purpose of the sustainable development is to promote the welfare of the society, improve people's both material and spiritual quality living quality. The ultimate goal of sustainable development is to promote the welfare of the society, and improve the people's material and spiritual living quality, which are served by both the economic growth and the protection of resources and environment. The economy sustainable development is the core of the whole system of the sustainable development. The ecology sustainable development is the natural foundation of economy sustainable development. The society sustainable development is the important guarantee for the economy sustainable development. And the economy sustainable development is the material conditions of ecology and society sustainable development.[2] According to the connotation and the requirements of sustainable development, Chongqing economy sustainable development includes the following five aspects: the level of economy development, the power of economy development, the factor supporting of economy development, the ecological constraints of economy development and the achievement distribution of economy development.

The level of economy development: reflecting the economy development of Chongqing city and its counties from the aspects of total economy output, economy structure, the development level of the three industries, revealing the prominent problems existing in the economy development of current Chongqing city and its counties.

The power of economy development: investigating the power of economy development of Chongqing city and its counties from the three aspects of investment, consumption, import and export, revealing the potential and shortage of each county economy development.

The supporting of economy development: reflecting the development level and potential of the science and technology, information, human resources, land and other factors which support the sustainable development of Chongqing city and its counties. [3]

The ecological constraints of economy development: reflecting the consumption level, environmental protection, resource constraints and other aspects that restrict the sustainable development of Chongqing city and its counties 
economy energy, revealing the limitations and constraints of the ecological environment.

The achievement distribution of economy development: reflecting the achievement of the economy development of Chongqing city and its counties, and the economy achievement distribution, such as the income, housing, savings, public services, social security and other social welfare, revealing the final goal of the economy sustainable development is to realize the social welfare.

\section{THE EVALUATION SYSTEM OF SUSTAINABLE DEVELOPMENT OF CHONGQING ECONOMY}

The author intends to establish a statistical system to measure the sustainable economy development of Chongqing City, whose purpose and function is to discover and describe the major problems in the economy development of Chongqing city. On this basis, we can evaluate the level of sustainable development and make judge on whether the economy development in Chongqing city is closer to or more away from sustainable development objective, then guide the economy development.

\subsection{The Design Principle of the Evaluation Index System}

The structure of regional complex system is mixed and has varied levels, we selected the most sensitive, measurable and meaningful leading indicators as the evaluation index. According to the characteristics and requirements of regional economy sustainable development, we determine the following principles for the construction of index system.

\subsection{The Scientific Principle}

This principle includes two levels of meaning: the first level, as to the choice of indicators, the weight of each indicator, the selection of reference data and the calculation method used for synthesis, we should recognize the scientific theory and take the relevant report, the academic theory, management science and other theories as the bases. The second level, as to the index selection, in addition the scientific conditions, due to that the index system plays a guiding and vital role nowadays and for the future for the development of regional economy, we should pay attention to whether the choice of index in this system is appropriate and overall and whether there are overlapping components among the indexes. If the selection of the index is not comprehensive enough, then the index system cannot reflect the status of regional economy sustainable development; on the contrary, if the index contains are overlap, then it may exaggerate the effect of one aspect while ignore the other aspects of the development of regional economy.

\subsection{The Principle of Objectivity}

This principle requires that all indexes that the index system involved, we should obtain the relevant data on the basis of fact and obey the objectivity of the scientific results in the calculation and the measurement process.

The principle of Comparability: This principle requires that we should adapt the international or domestic unified standard for the index selection, data acquisition, the method of calculation and measurement and the measurement units in the construction process of the index system to facilitate the relevant aspects of the horizontal and vertical comparison.

The Principle of Matching: The indicator system of region economy sustainable development is not a panacea and applicable to any sustainable development of regional economy. Different development of regional economy has different target content. Even in the cases that the different regions select the same index contents, there is different weight of the each index, which is determined by the concrete situation. So, there lies the matching problem between the development status of regional economy and the index system of sustainable development.

The Principle of Feasibility: The simplest requirement of the principle is that the proposed index and the reference of the index weight can be obtained by a certain effort and is feasible but not some unavailable data and materials.

The Principle of Guiding: This principle requires the explicit purpose of the index system construction of regional economy sustainable development, not only for the evaluation of the status of the regional economy sustainable development, but also to guide the future strategy of the regional economy sustainable development, then to track the evaluation results and point out the deficiency in the development of the economy regional, draw experiences and lessons to guide the future of the region economy sustainable development.

The Principle of Development: According to the actual economy situation of the regional economy sustainable development, the existing indicators should be adjusted and revised continuously to keep synchronous progress with the regional economy.[4]

\subsection{The Indexes of the Regional Economy Sustainable Development}

According to the connotation and requirements of sustainable development, the evaluation index system of the economy sustainable development of Chongqing is as following.[5] 
Table 1 The Evaluation Index System of Chongqing Economy Sustainable Development

\begin{tabular}{|c|c|c|c|}
\hline $\begin{array}{l}\text { The 1st class } \\
\text { indexes }\end{array}$ & $\begin{array}{l}\text { The 2nd class } \\
\text { indexes }\end{array}$ & The 3rd class indexes & The 4 th class indexes \\
\hline \multirow{33}{*}{$\begin{array}{l}\text { The level of } \\
\text { economy } \\
\text { development }\end{array}$} & \multirow{8}{*}{$\begin{array}{l}\text { The total amount } \\
\text { and structure of } \\
\text { economy }\end{array}$} & \multirow{6}{*}{ The total level } & GDP per capita \\
\hline & & & Revenue per capita \\
\hline & & & The total investment in fixed assets \\
\hline & & & The total retail sales of social consumer goods \\
\hline & & & The social total retail sales of consumer goods \\
\hline & & & The urbanization rate \\
\hline & & \multirow{2}{*}{$\begin{array}{l}\text { The structure } \\
\text { optimization }\end{array}$} & $\begin{array}{l}\text { The proportion of output value of the second and the third } \\
\text { industry }\end{array}$ \\
\hline & & & $\begin{array}{l}\text { The proportion of the production workers of the second and } \\
\text { the third industry }\end{array}$ \\
\hline & \multirow{9}{*}{$\begin{array}{l}\text { The agriculture } \\
\text { and rural }\end{array}$} & \multirow{2}{*}{$\begin{array}{l}\text { The agricultural } \\
\text { investment and benefit }\end{array}$} & $\begin{array}{l}\text { The productive fixed asset investment of the agricultural } \\
\text { population per capita }\end{array}$ \\
\hline & & & The agricultural investment benefit \\
\hline & & \multirow{4}{*}{$\begin{array}{l}\text { The construction of rural } \\
\text { economic organizations }\end{array}$} & $\begin{array}{l}\text { The number of ten-thousand rural cooperative economic } \\
\text { organization }\end{array}$ \\
\hline & & & $\begin{array}{l}\text { The proportion of the reform of the property right system of } \\
\text { the collective economic organization }\end{array}$ \\
\hline & & & The number of feature center of the town \\
\hline & & & The market rate of the agricultural product \\
\hline & & \multirow{3}{*}{$\begin{array}{l}\text { The factor of the rural } \\
\text { resources }\end{array}$} & The electricity consumption per capita of the rural population \\
\hline & & & $\begin{array}{l}\text { The aging degree of the rural population (the ratio of rural } \\
\text { labor above } 51 \text {-year- old) }\end{array}$ \\
\hline & & & $\begin{array}{l}\text { The quality of the rural labor force (the average number of } \\
\text { education years) }\end{array}$ \\
\hline & \multirow{7}{*}{ The industry } & \multirow{3}{*}{ The industry benefit } & $\begin{array}{l}\text { The value added of the industrial total output per 10- } \\
\text { thousand Yuan }\end{array}$ \\
\hline & & & The rate of cost to profit \\
\hline & & & The overall labor productivity of industrial enterprises \\
\hline & & $\begin{array}{l}\text { The scale and clustering } \\
\text { degree of the industry }\end{array}$ & The number of industrial enterprises above designated size \\
\hline & & $\begin{array}{l}\text { The development level of } \\
\text { high and new technology } \\
\text { industry }\end{array}$ & $\begin{array}{l}\text { The ratio of high technology manufacturing industry } \\
\text { production value (high technology industry production value } \\
\text { /GDP) }\end{array}$ \\
\hline & & \multirow{2}{*}{$\begin{array}{l}\text { The total output and } \\
\text { efficiency of the state- } \\
\text { owned and private } \\
\text { economy }\end{array}$} & $\begin{array}{l}\text { The proportion of added- value of the state-owned and } \\
\text { private industrial enterprises }\end{array}$ \\
\hline & & & $\begin{array}{l}\text { The ratio of cost to profit of the state-owned and private } \\
\text { industrial enterprises }\end{array}$ \\
\hline & \multirow{9}{*}{$\begin{array}{l}\text { The modern } \\
\text { service industry }\end{array}$} & The industry benefit & $\begin{array}{l}\text { The added-value of third industry total output value per ten- } \\
\text { thousand Yuan }\end{array}$ \\
\hline & & The tourism & Tourism income \\
\hline & & The culture & The added-value of cultural industry \\
\hline & & The logistics & The total freight volume \\
\hline & & & The port cargo throughput \\
\hline & & & The airport throughput \\
\hline & & $\begin{array}{l}\text { The business (wholesale } \\
\text { and retail) }\end{array}$ & $\begin{array}{l}\text { The commodity sales of the wholesale industry corporate } \\
\text { enterprise (wholesale) }\end{array}$ \\
\hline & & \multirow{2}{*}{ The finance } & The number of listing Corporation \\
\hline & & & The issuance of corporate bonds \\
\hline \multirow{5}{*}{$\begin{array}{l}\text { The power of } \\
\text { economic } \\
\text { development }\end{array}$} & \multirow{3}{*}{ The investment } & \multirow{2}{*}{ The benefit of investment } & Investment contribution rate \\
\hline & & & Investment multiplier \\
\hline & & The investment structure & $\begin{array}{l}\text { The ratio of the real estate development to the total social } \\
\text { investment in fixed assets }\end{array}$ \\
\hline & The consumntion & The level of con & $\begin{array}{l}\text { The proportion of the consumer spending and the total } \\
\text { expenditure of rural residents }\end{array}$ \\
\hline & the consumption & the rever or consumption & $\begin{array}{l}\text { The proportion of the consumer spending and the total } \\
\text { expenditure of urban residents }\end{array}$ \\
\hline
\end{tabular}




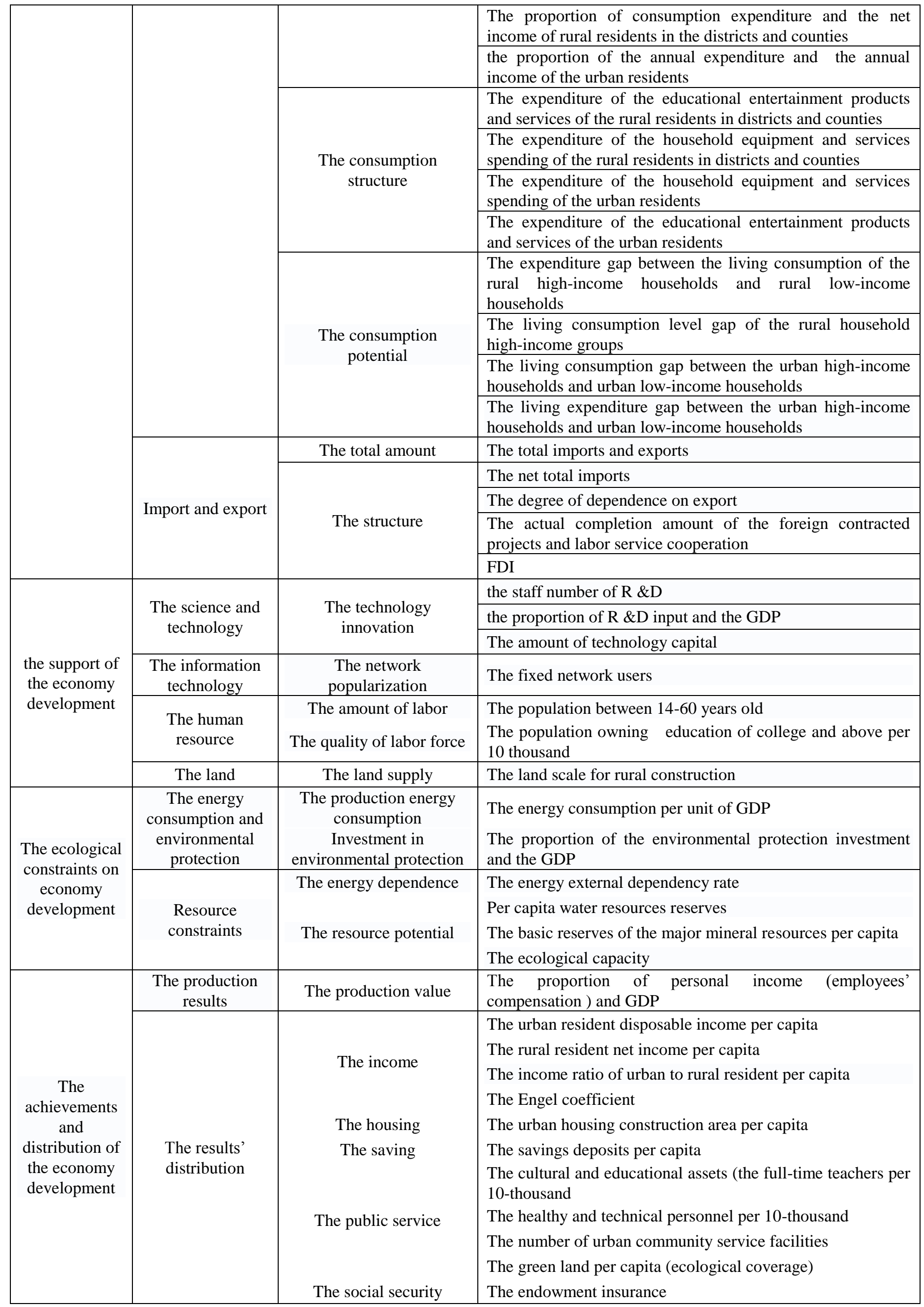




\subsection{The Conclusion}

In general, the total economic output of Chongqing showed a rising trend, the development of the regional economy and the unbalanced. The economic structure is not reasonable, especially the first industry and the third industry development is slow, the overall economic development level is not high. Lack of city infrastructure construction, social security and health status also need more improvement. The atmosphere and water environment situation is still not optimistic, centralized sewage treatment, garbage harmless treatment and disposal of hazardous waste serious shortage of capacity, especially the rural ecological environment. Further efforts are needed to achieve the sustainable development of economy, society, environment!

\section{REFERENCES}

[1] Introduction to regional sustainable development, the science press, 2014, 7.

[2] Environment and sustainable development introduction to science, China Press, 2014, 9.

[3] Sustainable economics, the China Social Sciences press, 2007, 1.

[4] Zhouliqin; The indicator system of regional sustainable development; contemporary finance 2013, 05.

[5] Liu Yi ; Regional sustainable development status and classification of China; geography; 2014, 05. 